\title{
Human Resource Management Practices and Employee's Turnover Intention in the Manufacturing Industry in Malaysia
}

\author{
Ong Choon Hee (Corresponding author) \\ Azman Hashim International Business School, \\ Universiti Teknologi Malaysia, 81310 Johor Bahru, Johor, Malaysia
}

Chew Mei Lien

Azman Hashim International Business School,

Universiti Teknologi Malaysia, 81310 Johor Bahru, Johor, Malaysia

Sim Jun Liang

Azman Hashim International Business School,

Universiti Teknologi Malaysia, 81310 Johor Bahru, Johor, Malaysia

Ainatul Shahirah Mohamed Ali

Azman Hashim International Business School,

Universiti Teknologi Malaysia, 81310 Johor Bahru, Johor, Malaysia

Nazhatul Shima Abd Manap

Azman Hashim International Business School,

Universiti Teknologi Malaysia, 81310 Johor Bahru, Johor, Malaysia

Siti Naqiah Lailee

Azman Hashim International Business School,

Universiti Teknologi Malaysia, 81310 Johor Bahru, Johor, Malaysia 
Received: April 11, 2018 Accepted: April 26, 2018 Online published: April 28, 2018

doi:10.5296/ijhrs.v8i2.13008

URL: https://doi.org/10.5296/ijhrs.v8i2.13008

\begin{abstract}
The main objective of this study is to examine the influence of Human Resource Management (HRM) practices (compensation and benefits, recruitment and selection and work-life policies) on employee's turnover intention. A survey questionnaire was sent and collected from 60 respondents who worked in the Manufacturing Industry in Malaysia. The results showed that the main factor that influences turnover intention of the employees was compensation and benefits. Hence, manufacturing firms ought to put extra efforts in this aspect in order to retain talents and minimize turnover rate of its workforce. Recruitment and selection and work-life policies were found to be not significant in predicting employee's turnover intention.
\end{abstract}

Keywords: turnover intention, HRM practices, compensation and benefits, recruitment and selection, work-life policies.

\title{
1. Introduction
}

\subsection{Background of the Study}

Manufacturing industry had started to grow steadily in Malaysia since 1990s. In conjunction with the nation's vision to become a developed and industrialized country, a lot of effort was put into attracting foreign investors to invest in the manufacturing industry in Malaysia. All these investor-friendly policies had driven Malaysia to become one of the main manufacturing hubs in Asia and helped to train and develop a pool of talented workforce. Owing to the competitiveness of this industry, each manufacturing company faces the challenge of retaining and hiring the most talented workforce for their own company in order to stay ahead in the market. Moreover, the competition to get the most talented employees was not within the country region only but also within the Asia Pacific region due to globalization effects. Firms from other Southeast Asia countries such as Vietnam, Thailand and Cambodia had started to hire skilled workers from Malaysia in their countries as expatriates. Therefore, it is important for HR practitioners in the manufacturing companies to be familiar and aware of the current scenario and the mind-set of employees in order to create effective policies that can assist the company to retain its employees and minimize turnover rate. During the process in retaining talented employees, first of all, the management needs to understand the main reasons which cause the employees to have the intention to leave the company. Hence, the objective of this research paper is to examine the influence of HRM practices on employee's turnover intention in the manufacturing industry in Malaysia. Numerous research papers have studied the influence of various HRM practices on turnover intention of employees. In this paper, we focus on studying the influence of three main HRM practices (compensation and benefits, recruitment and selection and work-life policies) on employees' turnover intention. The findings of this study would help HR practitioners to 
identify significant HRM practices that influence employee's turnover intention and formulate policies and strategies to retain employees who are able to contribute to the growth of the company.

\section{Literature Review}

\subsection{Turnover Intention}

The term turnover intention is often used in Human Resource Management. It is crucial for an organization to constantly monitor turnover rate amongst its employees. There are various visible and invisible costs of high employee turnover rates, such as recruitment, induction and training expenses (visible) and effect on morale of the remaining staff (invisible). It is likely that organizations may have underestimated these costs as highlighted by Ahlrichs (2000). According to Bester (2012), there is a general perception that this term is self-explanatory, and hence the precise definition of this term is rarely found. Nonetheless, in general, turnover intention can be defined as the last step before an employee decides to resign from their place of work (Horn, Griffeth \& Salaro, 1984; Mobley, 1982; Mowday, Steers, \& Porter, 1979; Steers, 1977). More specifically, in terms of duration, Medina (2012) defined it as an employee's commitment to find a new job with another employer within the next year. In a study of Medina (2012), the author had also explained about the general acceptance of the inverse relationship between job satisfaction and turnover intention. While turnover intention is seen from the employee's perspective, the flip side of this issue from the employer's angle would be employee retention. Organizations with best HRM practices generally understand the importance of managing talent and turnover intention. They consider employee retention as one of the strategic business plans (Farley, 2005). In a study of Oladapo (2014), the author stated that approximately two third of the organizations used human resource management strategies to retain talents, which was an increase from the results obtained by Lockwood (2006) where half of the organizations reported using human resource management strategies. According to Oladapo (2014), most of the human resource department personnel emphasized on internalizing and embracing basic aspects of HRM practices in retaining talents.

\subsection{Compensation and Benefits}

While compensation is defined as the financial returns and tangible benefits that an employee receives from the employer (Bernadin, 2007), benefits include non-financial payments that an employee received as he or she continues working for an organisation (Odunlade, 2012). A study of Zhou and Yang (2012) indicated that reward is the most important factor that influences job satisfaction and turnover intention. The employees often receive the rewards based on the job values, personal involvement, efforts and performance (Milkovich and Newman, 2005). Consequently, every employer has a vital duty to reward their employees based on their contribution and performance. The employees have the right to be rewarded fair and equitable manner. According to the Hoyt and Gerdloff (1999), compensation offers security, independence, recognition and an improved self-worth. A research on Thailand's manufacturing industry by Tangthong et. al (2014) revealed that compensation and benefits, training and development had significant direct and indirect effects on employee retention. Abdul Hameed et al. (2014) conducted a study on employee view towards compensation and 
benefits policy. The data were collected from 45 banks in southern Punjab. The authors randomly distributed questionnaires among 200 full-time working employees of banks. The study showed that salary; rewards and incentives and indirect compensation have a positive impact on employee performance and employee retention. Based on the above discussion, it is hypothesized that:

H1: Compensation and benefits will influence employee's turnover intention in the manufacturing industry.

\subsection{Recruitment and Selection}

Recruitment and selection is one of the HRM major practices to find and hire the best candidate to fit the job requirements. The recruitment and selection of the qualified candidates should either come from within or outside of an organization in a timely and cost effective manner. It includes analyze the job requirement, attracting candidates for the job, screening, hiring and integrating the new staff to the company. For employers, recruitment is the process of searching for potential employees and attracting them to apply for jobs in the company. The step that follows after recruitment is selection, whereby the most suitable person is chosen out of all applicants. Various sources of recruitment are available generally, for example internal recruitment (transfers, promotions, internal vacancies and etc.) and external recruitment (educational institutions, online, job agents and etc.). Jha and Bhattacharyya (2012) found that in order for companies to attract the most suitable and potential talent for employment, it is important that the selection process should be enhanced. An effective job selection process helps to pave the way for higher job satisfaction, because an individual will remember the good experience and thus have a good start to his or her job experience (Jha and Bhattacharyya, 2012). The realistic job previews can be used in the recruitment process to increase the possibility of adequate psychological contract at employee entry stage. Employees selected through realistic job previews will have lower turnover intention (Bonn and Forbringer, 1992). Following the above discussion, it is hypothesized that:

H2: Recruitment and selection will influence employee's turnover intention in the manufacturing industry.

\subsection{Work-Life Policies}

Work-life policies are a practice which usually refers to an organization giving support for dependent care, flexible working hours and permitting individuals for family or personal leaves (Estes \& Michael, 2005). Cappelli (2000) defined work-life policies as a main component that will affect employee's job satisfaction as well as organizational loyalty and productivity. It should assist employee retention if the company provides a workplace where all employees have the opportunities to maintain their work-life balance. The investment in work-life policies and practices is worthier if the policies are able to help employees to balance their work-life which in turn reduce their intention to leave their current job. Raduan et al. (2006) explains the quality of work life as how satisfied an employee is towards his or her work and lifestyle and able to prioritize them in a proper manner. A supportive work 
culture, balanced work and life activities alongside career development and compensation and benefits are amongst the factors that improve retention of employees (Messmer, 2006). However, it has to be noted that for those companies willing to ensure that work-life policies are effective, their workers must not be penalized either economically, socially or career-wise with the use of the policy. Recent research on retention factors also indicated that the ability to provide work life balance is a key factor in retaining professional and skilled employees (Joao, 2012). Based on the above discussion, it is hypothesized that:

H3: Work-life policies will influence employee's turnover intention in the manufacturing industry.

\subsection{Research Framework}

Figure 1 presents the research framework which consists of independent variables (HRM practices) and the dependent variable (turnover intention). There are several reasons for turnovers to occur among employees, depending on the types of industry, types of occupation, payment, supervisory levels, locations, selection processes, work environment, work assignments, benefits and promotions (Mobley, 1982). In addition, non-working factors such as family-related factors could also influence employee turnover in organizations (Mobley, 1982. Therefore, this research framework aims to examine that turnover intention that is triggered by the HRM practices of compensation and benefits, recruitment and selection and work-life policies.

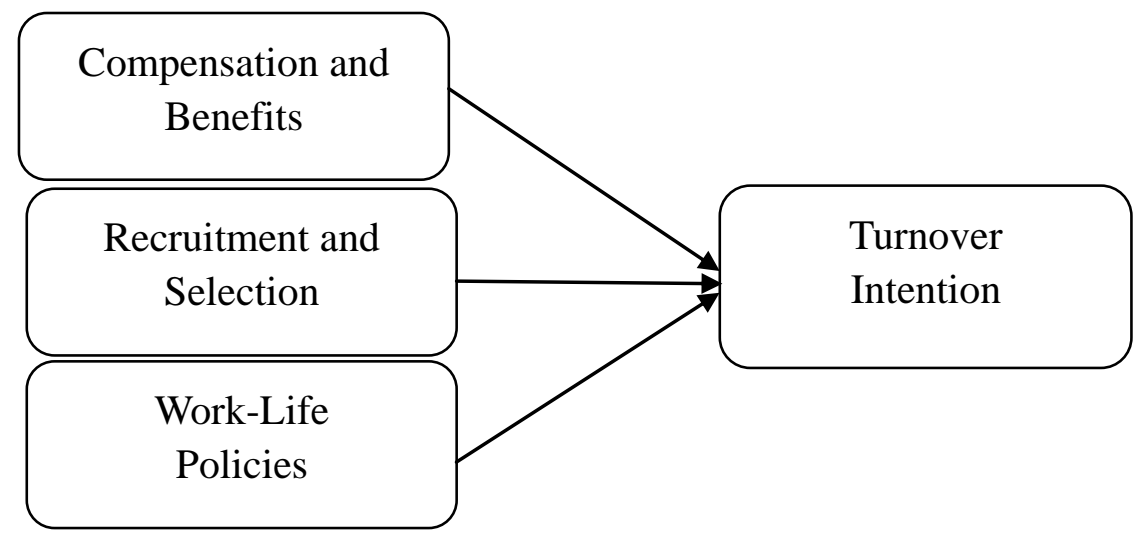

Figure 1. Research Framework

\section{Methodology}

\subsection{Sample}

The sample of this study consists of 60 respondents from various manufacturing companies located in Johor Bahru, Malaysia. Questionnaire survey method was employed by using purposive sampling method. Table 1 shows the respondents were consisted of 26 males and 34 females. Most of the respondents were aged between 26-30 years old (36.7\%). In terms of years of service, majority of the respondents have worked for $1-5$ years $(38.3 \%)$ in their workplace. 


\section{Macrothink \\ International Journal of Human Resource Studies

Table 1. Respondent's Demographic Characteristics

\begin{tabular}{|c|c|c|}
\hline Demographic Characteristics & Frequency & Percentage $(\%)$ \\
\hline \multicolumn{3}{|l|}{ Gender } \\
\hline Male & 26 & 43.3 \\
\hline \multirow{2}{*}{ Female } & 34 & 56.7 \\
\hline & 60 & 100 \\
\hline \multicolumn{3}{|l|}{ Age } \\
\hline $20-25$ & 15 & 25 \\
\hline $26-30$ & 22 & 36.7 \\
\hline $31-35$ & 8 & 13.3 \\
\hline $36-40$ & 10 & 16.7 \\
\hline $41-45$ & 4 & 6.7 \\
\hline \multirow[t]{2}{*}{$46-50$} & 1 & 1.6 \\
\hline & 60 & 100 \\
\hline \multicolumn{3}{|l|}{ Years of Service } \\
\hline$<1$ & 15 & 25 \\
\hline $1-5$ & 23 & 38.3 \\
\hline $6-10$ & 8 & 13.3 \\
\hline $11-15$ & 5 & 8.4 \\
\hline $16-20$ & 8 & 13.3 \\
\hline $21-25$ & 0 & 0 \\
\hline \multirow[t]{2}{*}{$26-30$} & 1 & 1.7 \\
\hline & 60 & 100 \\
\hline
\end{tabular}

\subsection{Measurements}

The turnover intention scale ( 3 items) established by Mobley (1982) was adopted in this study. For compensation and benefits, measures (5 items) by Heneman and Schwab (1985) were used it this study. Meanwhile, recruitment and selection was measured by measures ( 5 items) adapted from Edgar and Geare (2005). On the other hand, 5 items of measurement developed by Guy and Michel (2000) were employed to measure the perception of work-life policies among the respondents. All responses were rated on a 5-point Likert scale ranging from (1) 'strongly disagree' to (5) 'strongly agree'.

\subsection{Data Collection}

The data was gathered from the information in the survey form distributed to the target group, which are the employees in the manufacturing industry. The questionnaire was cautiously established for the purpose of gauging respondents' perceptions towards their current job. The questionnaires were given out and later collected either by hand or through online email. There were 60 complete and usable questionnaires returned by the respondents. All of the data gathered was analyzed using SPSS (Statistical Package for the Social Science). Five-point scale was chosen as it was believed to provide adequate choice for respondents as to reflect their true beliefs.

\section{Results}

Table 2 presents mean, standard deviations and correlation for the study variables. There were 
negative relationships between compensation and benefits, recruitment and selection, work-life policies and turnover intention. The reliability value $(\alpha)$ for compensation and benefits was 0.869 , recruitment and selection, 0.720 and work-life policies, 0.799 . Meanwhile, the Cronbach's alpha for turnover intention was 0.869. Since all the values of Cronbach's Alpha were above the minimum value of 0.7 as suggested by Devellis (2003), the measures of the study variables were deemed reliable and consistent throughout the study. Table 3 presents the regression results of the influence of human resource management practices on turnover intention. The results show that $13 \%(\mathrm{R} 2=0.130)$ of the variance in turnover intention had been significantly explained by compensation and benefit, recruitment and selection and work-life policies. The results also showed that compensation $(\beta=-0.365, p<$ $0.05)$ was the only significant factor in predicting turnover intention. Other variables were not significant in predicting turnover intention. Therefore, hypothesis one (H1) was accepted while hypothesis two (H2) and three (H3) were rejected.

Table 2. Reliability, Means, Standard Deviations and Correlation of the Study Variables

\begin{tabular}{lcccccc}
\hline \begin{tabular}{l} 
Variables \\
\multicolumn{1}{c}{$\alpha$}
\end{tabular} & $\alpha$ & $\mathrm{M}$ & $\mathrm{SD}$ & 1 & 2 & 3 \\
\hline 1 Turnover Intention & 0.869 & 2.88 & 0.88 & 1 & & \\
2 Compensation \& Benefit & 0.869 & 2.82 & 0.77 & $-0.344^{* *}$ & 1 & \\
3 Recruitment \& Selection & 0.720 & 3.15 & 0.63 & -0.031 & $0.360^{* *}$ & 1 \\
4 Work-Life Policies & 0.799 & 3.57 & 0.61 & -0.166 & $0.396^{* *}$ & 0.250 \\
$\quad$ & & & & & & \\
\hline
\end{tabular}

Notes: $\mathrm{n}=60 ;{ }^{* *} \mathrm{p}<0.01 ;{ }^{*} \mathrm{p}<0.05 ; \alpha=$ Cronbach's Alpha, $\mathrm{M}=$ mean, $\mathrm{SD}=$ standard deviation

Table 3. Multiple Regression Results of HRM Practices on Turnover Intention

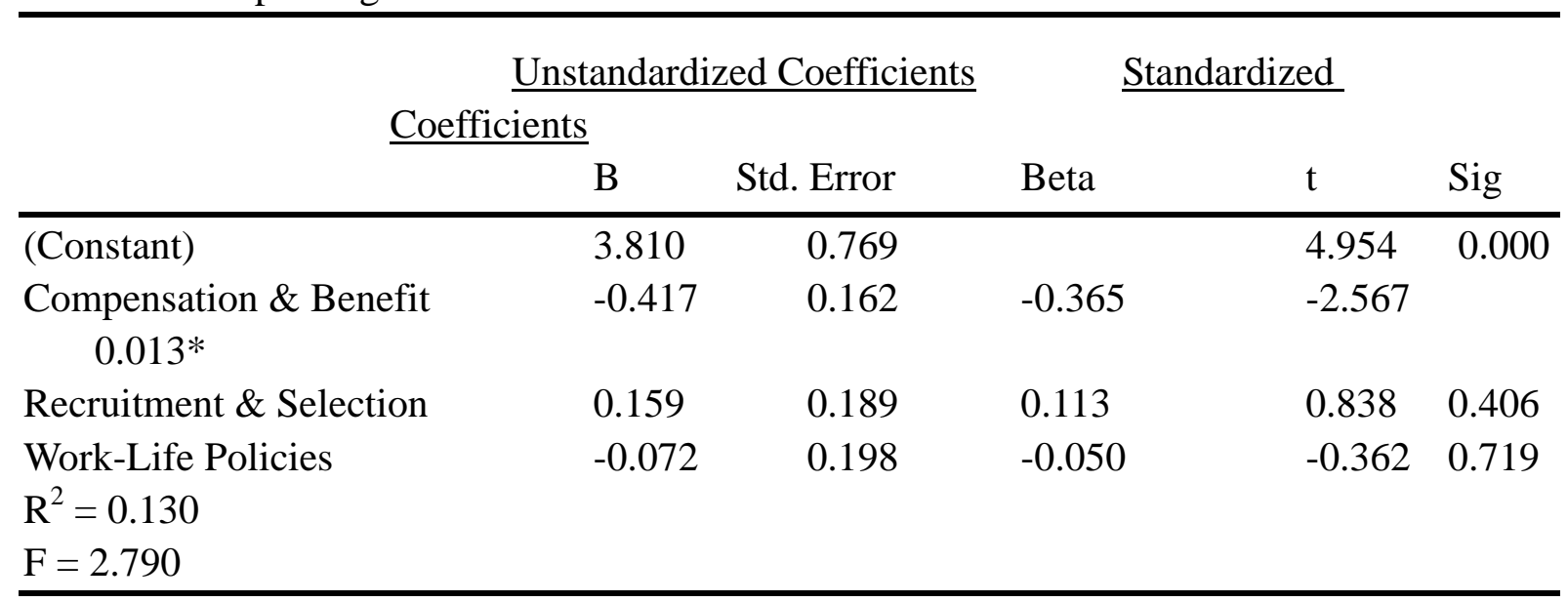

Notes: $* * \mathrm{p}<0.01 ; * \mathrm{p}<0.05$

\section{Discussion}

The purpose of this study is to examine the influence of HRM practices (compensation and benefit, recruitment and selection, work-life policy) on turnover intention in the manufacturing industry. This research reveals that there was significant negative association 
between compensation and benefit and turnover intention. This is corroborated by a research which indicated that employees who tend to show positive feeling towards compensation and benefit are likely to report lower level of turnover intention. The research involved data from 583 participants in Hong Kong and 121 participants in China, it revealed that compensation and benefits are important to retain and motivate employees (Randy et al., 2002). On the other hand, although it is generally believed that HRM practices of recruitment and selection and work-life policy would also have an influence on employee's turnover intention, the results of this study indicate otherwise. There is no significant relationship between recruitment and selection, work-life policies and turnover intention. This perhaps can be explained by the fact that recruitment and selection is a process that takes place before a prospective employee joins the firm, and once the person decides to join the firm, that process is no longer as relevant to his or her job and subsequently loyalty to the firm. Most employees treat recruitment and selection process as a standard procedure with relatively similar method across companies in the same industry, and are unlikely to allow this to be a key factor influencing them to remain in a company. As for work-life policies, few researches had shown that implementation of work-life policies can be helpful in attracting new employees and improving the attitude and behavior of employees (Beauregard, 2006), hence lowering turnover rate. However, in this study, work-life policies were found not significantly related to turnover intention. Among plausible reasons to explain this finding is that workers in Malaysia tend to be tolerant to less than ideal work-life policies, and treat it as a normal practice to be experienced as an employee. For example, most employees accept the traditional way of workstyles where one should not leave the office earlier than the boss and they also believe that being reliable and accessible after office hours are qualities that the bosses are looking for especially amongst the older generation bosses. In addition, employees tend to perceive work-life policies in most manufacturing firms in Malaysia as relatively similar, and hence believe that the grass may not be greener on the other side. Therefore, these reasons explain the finding that work-life policies remain not a key factor in influencing the intention of an employee to move to another organization.

\section{Conclusion}

This study attempts to test the relationship between HRM practices and turnover intention. The results indicated a significant relationship between compensation and benefits and turnover intention. For an organization to achieve its goals, it needs to be aware that its employee's satisfaction, loyalty and commitment to the organization are strongly associated with compensation and benefits. This factor cannot be taken lightly if an organization is hoping for its employee to chart his or her career with the organization in the long run. According to Abassi \& Hollman (2000), it was identified that lack of recognition and lack of competitive compensation systems are the reasons for employee's turnover intention. Frye (2004) classified that for human capital intensive organizations, compensation and benefits play a vital role in "attracting and retaining highly skilled employees". Organizations can also link its compensation and benefits with performance appraisal. It is suggested that future research is to examine the relationship between HRM practices and turnover intention in other industries to ensure the effectiveness of manpower planning and talent management in 
the organization.

\section{Acknowledgements}

The authors wish to thank the Malaysian Ministry of Higher Education and Universiti Teknologi Malaysia (Vot: 14J81) for providing financial support to publish this paper.

\section{References}

Abbasi, S., \& Hollman, K. (2000). Turnover: The Real Bottom-line. Public Personnel Management, 29(3), 333-342. https://doi.org/10.1177/009102600002900303

Abdul, H., Muhammad, R., Hafiz, M. K. Z., Ghazanfar, A., \& Muhammad, A. (2014). Impact of compensation on employee performance (empirical evidence from banking sector of Pakistan). International Journal of Business and Social Science, 5(2), 302-309.

Ahlrichs, N. S. (2000). Competing for Talent: Key Recruitment and Retention Strategies for Becoming an Employer of Choice. Davies-Black Publishing.

Beauregard, T. A. (2006). Predicting interference between work and home: A comparison of dispositional and situational antecedents. Journal of Managerial Psychology, 21(3), 244-264. https://doi.org/10.1108/02683940610659588

Bernadin, H. (2007). Human Resource Management: An Exponential Approach, 4th ed NewYork: McGraw-Hill Irwin.

Bester, F. (2012). A model of work identity in multicultural work settings. Unpublished DPhil thesis, University of Johannesburg, Johannesburg.

Bonn, M. A., \& Forbringer, L. R. (1992). Reducing turnover in the hospitality industry: an overview of recruitment, selection and retention. International Journal of Hospitality Management, 11(1), 47-63. https://doi.org/10.1016/0278-4319(92)90035-T

Capelli, P. (2000). A market-driven approach to retaining talent, Harvard Business Review, 78(1), 103-11.

DeVellis, R. F. (2003). Scale development: Theory and applications (2nd ed.), California: Sage.

Edgar, F., \& Geare, A. (2005). HRM practise and employee attitudes: Difference measures and different results. Personnel Review, 34(5), 534-549. https://doi.org/10.1108/00483480510612503

Estes S. B., \& Michael, J. (2005). Work-family policies and gender inequality at work: A Sloan Work and Family Encyclopedia entry. Retrived from http://workfamily.sas.upenn.edu/search/apachesolr_searc h/estes.

Farley, C. (2005). HR's role in talent management and driving business results. Employee Relations Today, 32(1), 55-61. https://doi.org/10.1002/ert.20053

Frye, M. (2004), Equity-Based Compensation for Employees: Firm Performance and 
Determinants, Journal of Financial Research, 27, 31-54. https://doi.org/10.1111/j.1475-6803.2004.00076.x

Guy, P., \& Michel, T. (2000). The measurement and antecedents of turnover intention among IT professionals. Scientific Series, Montreal, September 2000. Cirano Publications, 1-38.

Heneman, H. G. III., \& Schwab, D. P. (1985). Pay satisfaction: Its multidimensional nature and measurement. International Journal of Psychology, 20(2), 129-141.

Horn, P. W., Griffeth, R. W., \& Sellaro, L. (1984). The validity of Mobley's (1977) turnover model. Organizational Behavior and Human Performance, 34, 141-174. https://doi.org/10.1016/0030-5073(84)90001-1

Hoyt, J., \& Gerdloff, E. A. (1999). Organisational environment, changing economic conditions and the effective supervision of technical personnel: a management challenge. Journal of High Technology Management Research, 10(2), 275-294. https://doi.org/10.1016/S1047-8310(99)00014-0

Jha, S., \& Bhattacharyya, S. (2012). Study of Perceived Recruitment Practices and their Relationships to Job Satisfaction. Synergy, X(I).

Joao, T. (2012). Job retention factors, perceived career mobility and organisational commitment in the South African financial sector. Journal of Psychology in Africa, 69-76.

Lockwood, N. R. (2006). Talent management: Driver for organization success. Research Quarterly, 1-13. Retrieved September 8, 2007, from http://www.shrm.org

Medina, E. (2012). Job Satisfaction and Employee Turnover Intention: What does Organizational Culture Have to Do with It? Columbia University Masters of Arts.

Messmer, M. (2006). Four keys to improved staff retention. Strategic Finance, 88(4), 13-14.

Milkovich, G. T., \& Newman, J. (2005). Compensation. New York: McGraw-Hill Companies, Inc.

Mobley, W. H. (1982). Some unanswered questions in turnover and withdrawal research. Academy of Management Review, 7, 111-116. https://doi.org/10.5465/AMR.1982.4285493

Mowday, R., Steers, R., \& Porter, L. (1979). The measurement of organizational commitment. $\begin{array}{lllll}\text { Journal of } & \text { Vocational } & \text { Behaviour, } & 14, & 247 .\end{array}$ https://doi.org/10.1016/0001-8791(79)90072-1

Odunlade, R. O. (2012). Managing employee compensation and benefits for job satisfaction in libraries and information centres in Nigeria. Library Philosophy and Practice, 714.

Oladapo, V. (2014). The impact of talent management on retention. Journal of Business Studies Quarterly, 5(3).

Raduan, C. R., LooSee, B., Jegak, U., \& Khairuddin, I. (2006). Quality of Work Life: Implications of Career Dimensions. Journal of Social Sciences, 2, 61-67. https://doi.org/10.3844/jssp.2006.61.67 


\section{Macrothink}

International Journal of Human Resource Studies

ISSN 2162-3058 2018, Vol. 8, No. 2

Randy, K. C., Vivienne, W. L., \& Thomas, L. T. (2002). Personnel Review, 31(4), 44-56.

Steers, R. (1977). Antecedents and outcomes of organizational commitment. Administrative Science Quarterly, 22(1), 46-56. Steers, R. (1977). Antecedents and outcomes of organizational commitment. Administrative Science Quarterly, 22 (1), 46-56. http://dx.doi. org/10.2307/2391745

https://doi.org/10.2307/2391745

Tangthong, S., Trimetsoontorn, J., \& Rojniruntikul, N. (2014). HRM Practices and Employee Retention in Thailand - A literature review. International Journal of Trade, Economics and Finance, 5(2). https://doi.org/10.7763/IJTEF.2014.V5.362

Zhou J., \& Yang, L. Q. (2012). Study on Total Compensation Optimization Based on Employees' Needs. Industrial Engineering and Management, 17(3), 108-116.

\section{Copyright Disclaimer}

Copyright for this article is retained by the author(s), with first publication rights granted to the journal.

This is an open-access article distributed under the terms and conditions of the Creative Commons Attribution license (http://creativecommons.org/licenses/by/4.0/). 